\title{
Article \\ GIS-Based Site Suitability Analysis for Solar Power Systems in Mongolia
}

\author{
Uranchimeg Munkhbat and Yosoon Choi * (D) \\ Department of Energy Resources Engineering, Pukyong National University, Busan 48513, Korea; \\ 960627uranchimeg@naver.com \\ * Correspondence: energy@pknu.ac.kr; Tel.: +82-51-629-6562; Fax: +82-51-629-6553
}

Citation: Munkhbat, U.; Choi, Y. GIS-Based Site Suitability Analysis for Solar Power Systems in Mongolia. Appl. Sci. 2021, 11, 3748. https:// doi.org/10.3390/app11093748

Academic Editors: Marco Beccali and Tomonobu Senjyu

Received: 26 February 2021

Accepted: 19 April 2021

Published: 21 April 2021

Publisher's Note: MDPI stays neutra with regard to jurisdictional claims in published maps and institutional affiliations.

Copyright: (c) 2021 by the authors. Licensee MDPI, Basel, Switzerland. This article is an open access article distributed under the terms and conditions of the Creative Commons Attribution (CC BY) license (https:/ / creativecommons.org/licenses/by/ $4.0 /)$.

\begin{abstract}
In this study, we employed a geographic information system (GIS)-based approach to identify sites suitable for large-scale solar photovoltaic (PV) power plant installations in Mongolia. Accordingly, cells of $30 \times 30 \mathrm{~m}$ were used, and data based on seven criteria, including annual global horizontal radiation, annual average temperature, elevation, slope, slope direction (aspect), and distances from main roads and major power lines, were collected for each cell. GIS layers for these seven criteria were then converted into rated value layers using four grades. The weightings applied to the seven criteria were determined, using an analytical hierarchy process, by ten solar field experts. By combining the seven rating value layers with the weightings, a site suitability map was developed, using good, fair, low, and poor suitability grades. The results showed that sites graded as good, fair, low, and poor accounted for $3.27 \%, 53.06 \%, 42.59 \%$, and $1.08 \%$ of the total surface area, respectively. Good sites were predominantly located in the southern and central regions of Mongolia. As the current demand for electric power in southern and central regions is low and high, respectively, we concluded that the central region of Mongolia should be prioritized for installing PV power plants.
\end{abstract}

Keywords: renewable energy; site evaluation; analytic hierarchy process; geographic information system; solar energy; Mongolia

\section{Introduction}

The Energy Information Administration (EIA) expects global energy consumption to grow by approximately 50\% between 2018 and 2050 [1]. Fossil fuels are becoming increasingly expensive and elusive, and limited access to fossil fuels in the long run will lead to high prices. Therefore, in recent years, many countries have formulated policies aiming at reducing their energy costs and reliance on fossil fuels.

With increasing awareness regarding the risks of climate change, many countries have undertaken strategies for a transition to low-carbon economies. This has led to a focus on the use of renewable energy sources, as they are generally considered "clean", with a considerably lower impact on the environment than other energy sources [2]. Renewable energy accounted for $26.2 \%$ of global electricity generation in 2018 , which is expected to grow to $45 \%$ by 2040 , making renewable energy the fastest growing source of electricity [3].

Solar energy is an unlimited and clean renewable energy source, which is gradually replacing non-renewable energy sources [4]. Solar power generation has become one of the fastest growing renewable energy sources. As the price of solar panels is steadily declining, and various stimulus policies are being implemented, the growth rate of photovoltaic (PV) energy is increasing. PV energy is considered one of the most promising energy alternatives, owing to its ubiquitous and sustainable nature [5].

In recent years, many studies have identified suitable sites for PV power plants. A suitable site for solar installation depends not only on the amount of solar radiation received, but also on other technical, economic, environmental, and social factors-such 
as local topography, the need to conserve protected areas, environmental impact, water availability, and urban development. Therefore, site selection is not simple. All of these factors-as well as the scope for expansion, proximity to urban areas and roads, and access to power grids-need to be considered [6].

To address these issues, multiple-criteria decision analysis (MCDA; also known as multiple-criteria decision-making or MCDM) has been widely used, in conjunction with geographic information systems (GIS), in many studies [7]. MCDA has been applied to energy issues such as energy planning, site selection, resource allocation, energy exploitation, energy policy, building energy management, and transportation energy management [8]. Among the various MCDA methods, the analytic hierarchy process (AHP) has been commonly used for evaluating site suitability for solar power plants (Table 1). Uyan [9] analyzed site suitability for PV solar farms in Karapinar, Turkey, using GIS and the AHP. Using the AHP, Ziuku et al. [10] determined the weights of criteria for analyzing site suitability for concentrated solar power (CSP) plants. In addition, a combination of GIS and the AHP has been used to identify the most suitable sites for PV system installations in southern England [11], Tanzania [12], Saudi Arabia [5], West Africa [13], and Morocco [2,14]. Some studies used an integrated method of fuzzy logic and the AHP in order to evaluate site suitability for PV systems in Iran [15,16], Korea [17], and Spain [18]. However, no study has investigated site suitability for PV systems, using GIS and the AHP, in Mongolia.

Table 1. Summary of previous studies that analyzed site suitability for solar power plants using geographic information systems (GIS) and the analytic hierarchy process (AHP).

\begin{tabular}{ccccc}
\hline Reference & Plant Type & $\begin{array}{c}\text { MCDA } \\
\text { Method }\end{array}$ & Country & Scale \\
\hline Uyan [9] & PV, CSP & AHP & Turkey & Regional \\
\hline Ziuku et al. [10] & CSP & AHP & Zimbabwe & National \\
\hline Watson and Hudson [11] & PV, CSP & AHP & England & Regional \\
\hline Aly et al. [12] & PV, CSP & AHP & Tanzania & National \\
\hline Al Garni and Awasthi [5] & PV & AHP & Saudi Arabia & National \\
\hline Yushchenko et al. [13] & PV, CSP & AHP & West Africa & Continental \\
\hline Tahri et al. [2] & PV & AHP & Morocco & Regional \\
\hline Merrouni et al. [14] & PV & AHP & Morocco & Regional \\
\hline Asakereh et al. [15] & PV & Fuzzy AHP & Iran & Regional \\
\hline Noorollahi et al. [16] & PV & Fuzzy AHP & Iran & National \\
\hline Suh and Brownson [17] & PV & Fuzzy AHP & Korea & Regional \\
\hline Sánchez-Lozano et al. [18] & PV & Fuzzy AHP & Spain & Regional \\
\hline
\end{tabular}

The purpose of this study was to use a combination of GIS and the AHP to map the most suitable sites for PV power plants in Mongolia. Mongolia has enormous solar energy resources that can potentially be used to strengthen its energy security, reduce pollution, meet its global climate commitments, and develop regional electricity exports. To place Mongolia's abundant solar energy resources into economic circulation and attract foreign investors, it is initially necessary to identify suitable PV system installation sites. A large national-scale GIS database was constructed, which includes seven criteria layers representing site characteristics and their relative weightings calculated using the AHP. Finally, a GIS tool was used to generate compound site indexes, which were then applied to create a location compatibility map, with the country divided into four potential location groups: good, fair, low, and poor. 


\section{Study Area}

Mongolia is a sovereign state located across east and central Asia, with an area of $1,564,116 \mathrm{~km}^{2}$, and is the 18th-largest country in the world. It has a population of over 3.3 million, and $0.43 \%$ of the territory is covered by surface water [19]. It is a landlocked country, bordered by Russia to the north and China to the south. It has a diverse geography, being mostly covered with grassy steppes, with mountains to the north and west, and the Gobi Desert to the south (Figure 1). Ulaanbaatar, the capital and the largest city, is home to approximately $45 \%$ of the country's population.

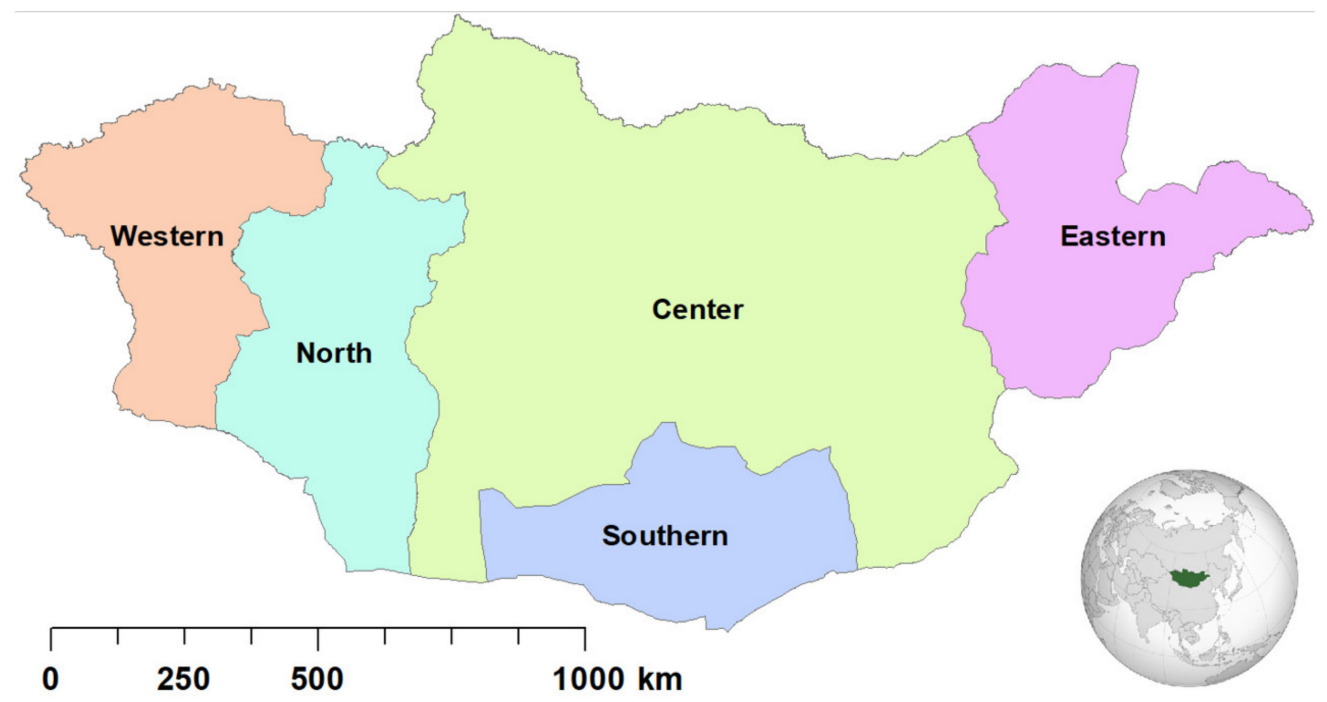

Figure 1. Map of Mongolia.

Mongolia has an average annual electricity consumption of 8.5 billion $\mathrm{kWh}$, of which $20 \%$ is imported [20], with the Oyu Tolgoi plant receiving most of its imported electricity (approximately 1.4 billion $\mathrm{kWh}$ ) from China [21]. Approximately 300 million $\mathrm{kWh}$ of electricity is imported annually from Russia [22].

In addition to the huge mineral deposits that contribute significantly to the national economy and increase export earnings, Mongolia is rich in solar energy resources. The entire country is cloud-free for 270-300 days annually, with annual average sunshine of $2250-3300 \mathrm{~h}$, delivering $1200-1600 \mathrm{~kW} / \mathrm{m}^{2}$ at an average radiation intensity of $>4.3-4.7 \mathrm{kWh} / \mathrm{m}^{2} /$ day [23]. Therefore, by exploiting more solar energy, Mongolia could export electricity to other countries rather than importing it.

\section{Methods}

\subsection{Selection of Criteria and Data Collection}

Selecting the criteria for rating is an important step in any site suitability assessment process for PV systems. Table 2 shows the criteria considered in previous studies that analyzed site suitability for PV systems. Among them, this study considered seven criteria to analyze the PV site suitability of Mongolia, in consideration of the availability of data at the national scale: global horizontal irradiance (GHI), temperature, elevation, slope, aspect, distance from a main road, and distance from a major power line (Figure 2). 
Table 2. Criteria considered in previous studies for analyzing photovoltaic (PV) site suitability.

\begin{tabular}{|c|c|c|c|c|c|c|c|c|c|c|}
\hline Reference & C1 & $\mathrm{C} 2$ & $\mathrm{C} 3$ & $\mathrm{C} 4$ & C5 & C6 & $\mathrm{C} 7$ & $\mathrm{C} 8$ & C9 & C10 \\
\hline Uyan [9] & & & $x$ & & & $x$ & $x$ & $X$ & $x$ & \\
\hline Watson and Hudson [11] & & & $X$ & $x$ & & $X$ & & & $X$ & \\
\hline Aly et al. [12] & $x$ & & & & & $X$ & $X$ & $X$ & & $x$ \\
\hline Al Garni and Awasthi [5] & $x$ & $X$ & $x$ & $x$ & & $X$ & & $X$ & & \\
\hline Yushchenko et al. [13] & $x$ & & & & & $X$ & $X$ & $X$ & & \\
\hline Tahri et al. [2] & $x$ & $x$ & $X$ & & & $X$ & $x$ & & $x$ & \\
\hline Merrouni et al. [14] & $x$ & & $X$ & & & $X$ & $X$ & $X$ & & $x$ \\
\hline Asakereh et al. [15] & & & $X$ & $X$ & $X$ & & $X$ & $X$ & $X$ & \\
\hline Noorollahi et al. [16] & $x$ & $X$ & $X$ & & $x$ & $X$ & $X$ & $X$ & $X$ & \\
\hline Suh and Brownson [17] & $x$ & $x$ & $X$ & & & & $X$ & $X$ & $X$ & \\
\hline Sánchez-Lozano et al. [18] & $x$ & $X$ & $X$ & & & $X$ & $x$ & $X$ & & \\
\hline
\end{tabular}

C1: Global horizontal irradiance, C2: temperature, C3: slope, C4: aspect, C5: elevation, C6: distance from a residential area, C7: distance from a road, C8: distance from a power line, C9: land use, C10: waterbody.

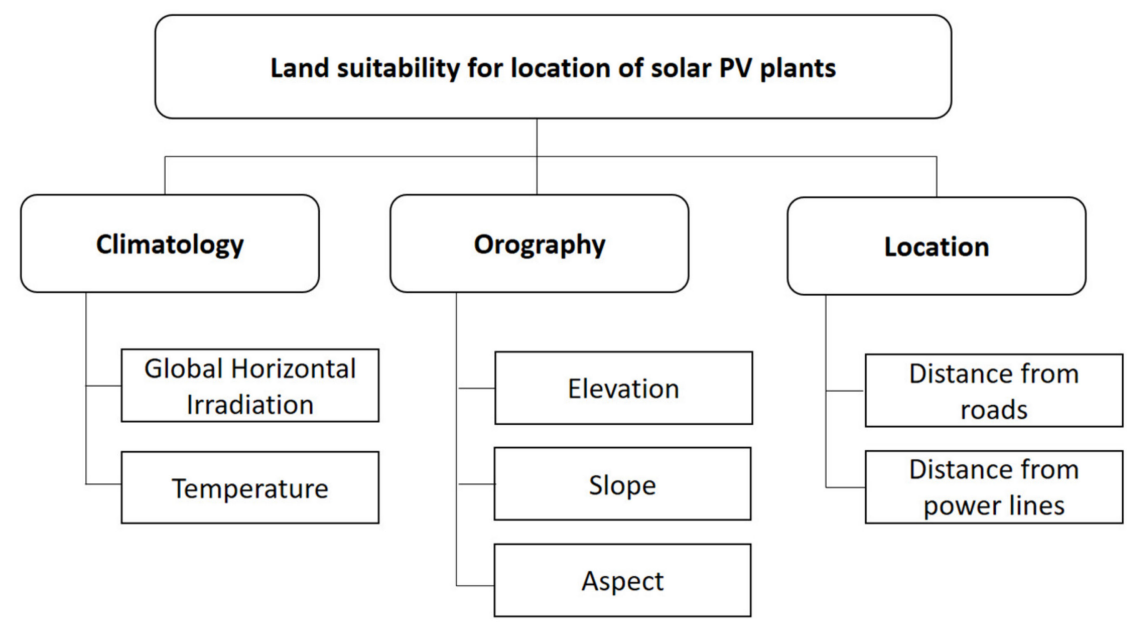

Figure 2. Selection criteria used in PV site suitability analysis in Mongolia.

GHI is the total amount of microwave radiation received by a horizontal surface on the ground. This value is interesting for light electrical installations, and includes both direct normal radiation (DNI) and diffuse horizontal irradiance (DHI). Figure 3 shows the GHI for Mongolia, generated using data from the Global Solar Atlas [24].

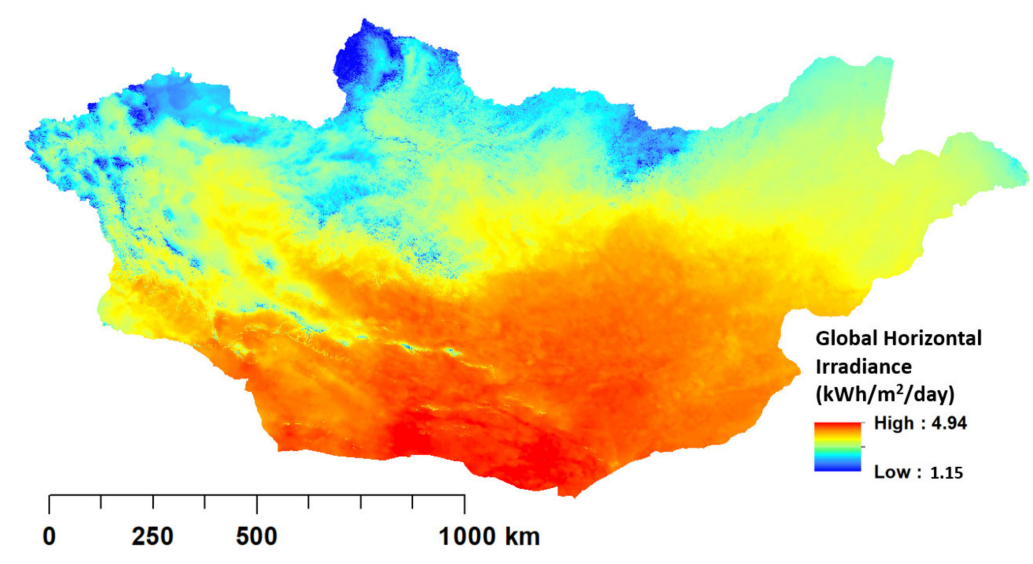

Figure 3. Global horizontal irradiance of Mongolia. 
The efficiency of a solar panel depends on its temperature, which in turn depends on both the ambient temperature and the intensity of the incoming solar radiation. Mongolia's annual climate cycle involves four seasons, which are characterized by high temperature fluctuations, low precipitation, and conspicuous latitudinal and altitudinal differences. The average temperature varies between -4 and $10{ }^{\circ} \mathrm{C}$ across the four seasons [25], and annual average temperatures are illustrated in Figure 4.

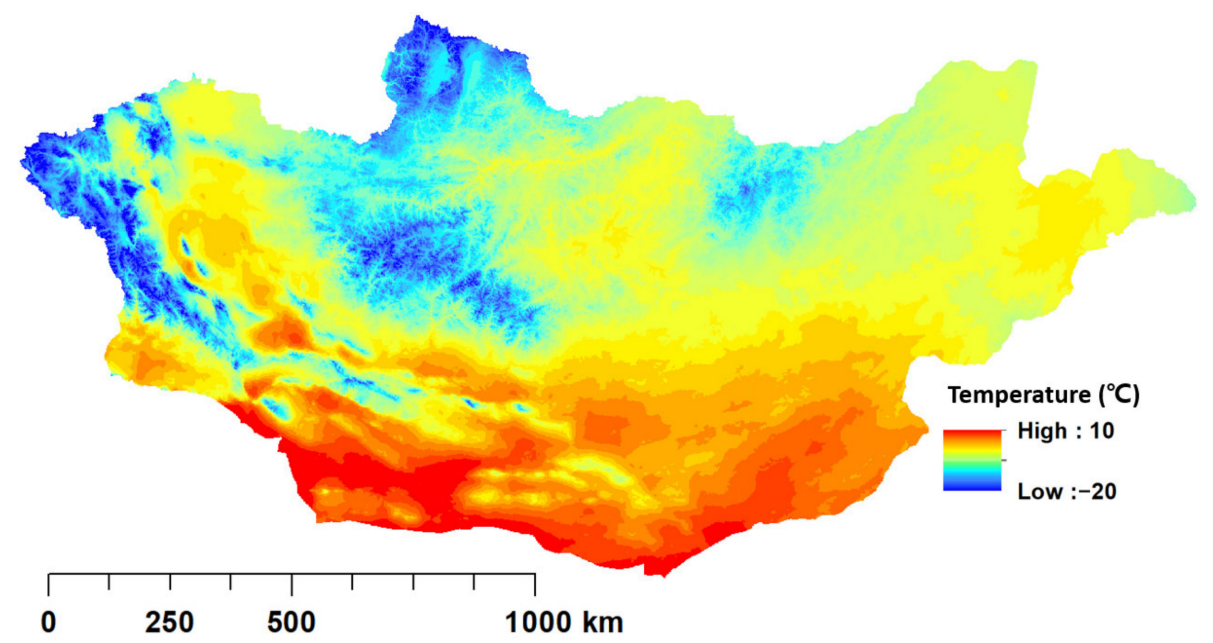

Figure 4. Annual average temperatures in Mongolia.

The highlands receive more solar radiation than the lowlands. The Mongolian Plateau is the second-largest plateau in central and east Asia [26], surrounded by the Gobi Desert to the south and the southeast, at an altitude of 523-4318 $\mathrm{m}$ above sea level-as shown in Figure 5, which displays a digital elevation model (DEM) of Mongolia, with a resolution of $30 \mathrm{~m}$.

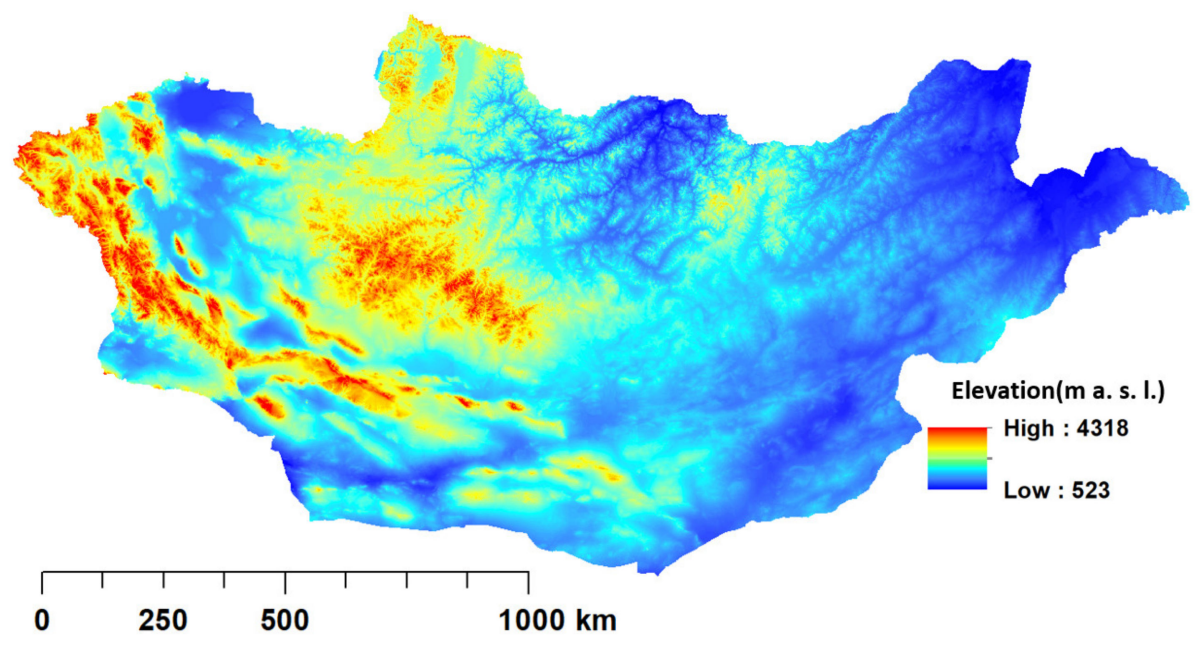

Figure 5. Elevation of Mongolia developed using a digital elevation model.

The slope and aspect of a site are considered important parameters for site selection for PV systems, as they determine the amount of radiation received by the solar panels. Figures 6 and 7 illustrate Mongolian slope and aspect data, as generated from the DEM of Mongolia. 


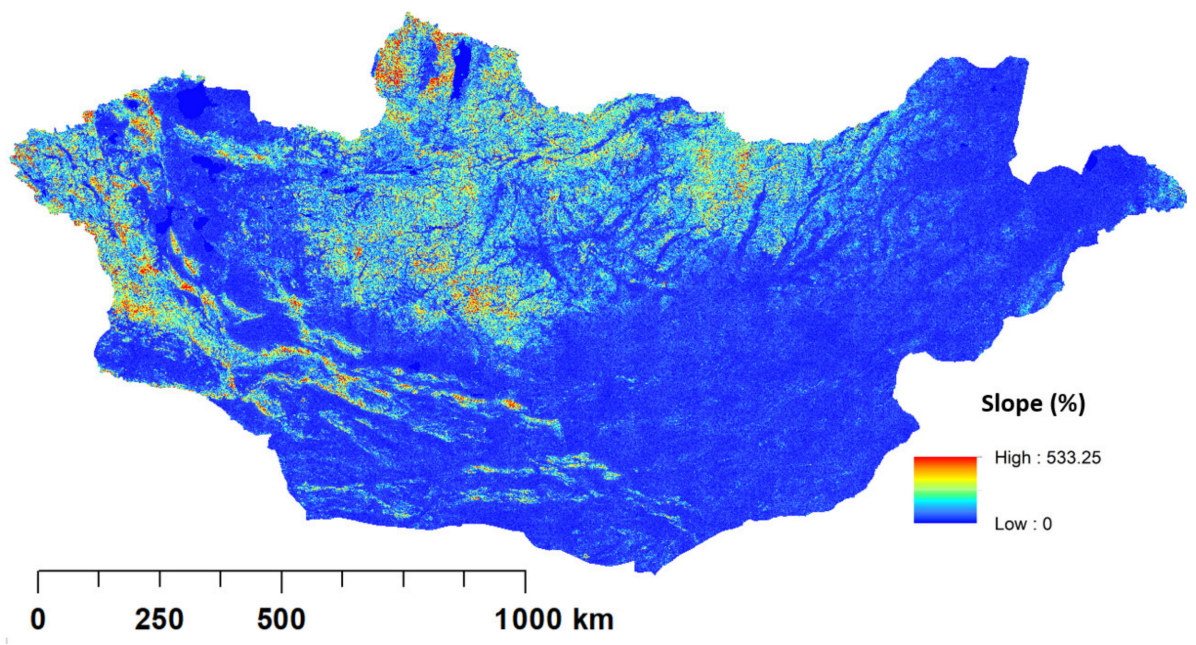

Figure 6. Slopes of Mongolia derived from a digital elevation model.

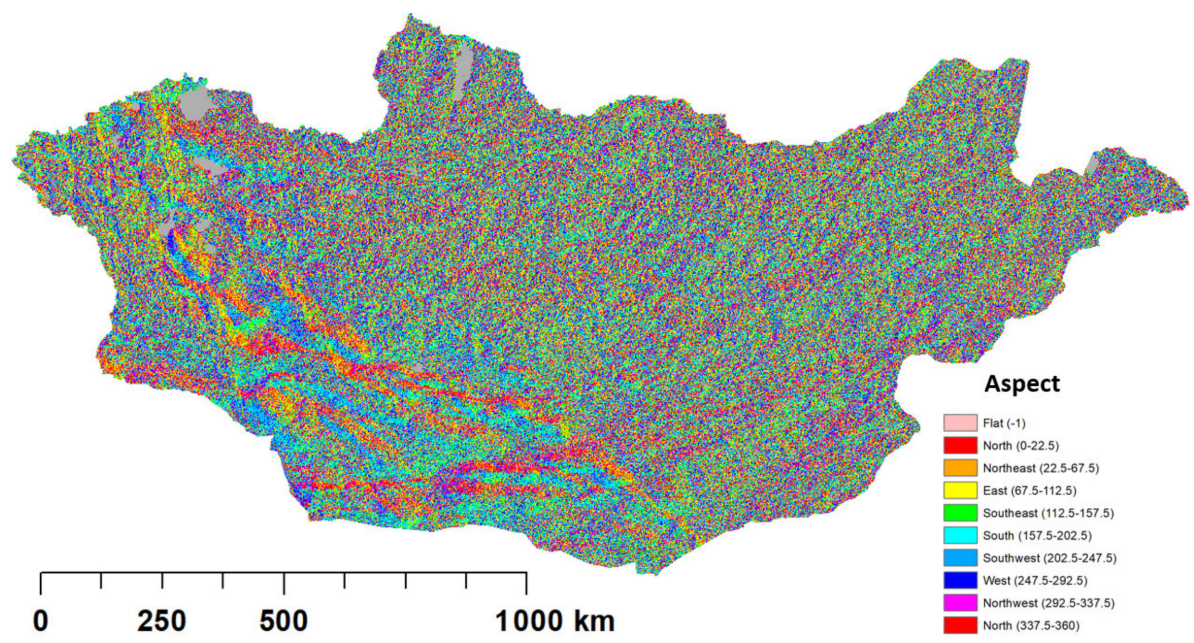

Figure 7. Aspect data for Mongolia, derived from a digital elevation model.

Proximity to main roads and major power transmission lines affects the cost of infrastructure construction and the associated environmental damage [12,27]. The major Mongolian main roads and power transmission lines are illustrated in Figures 8 and 9, respectively.

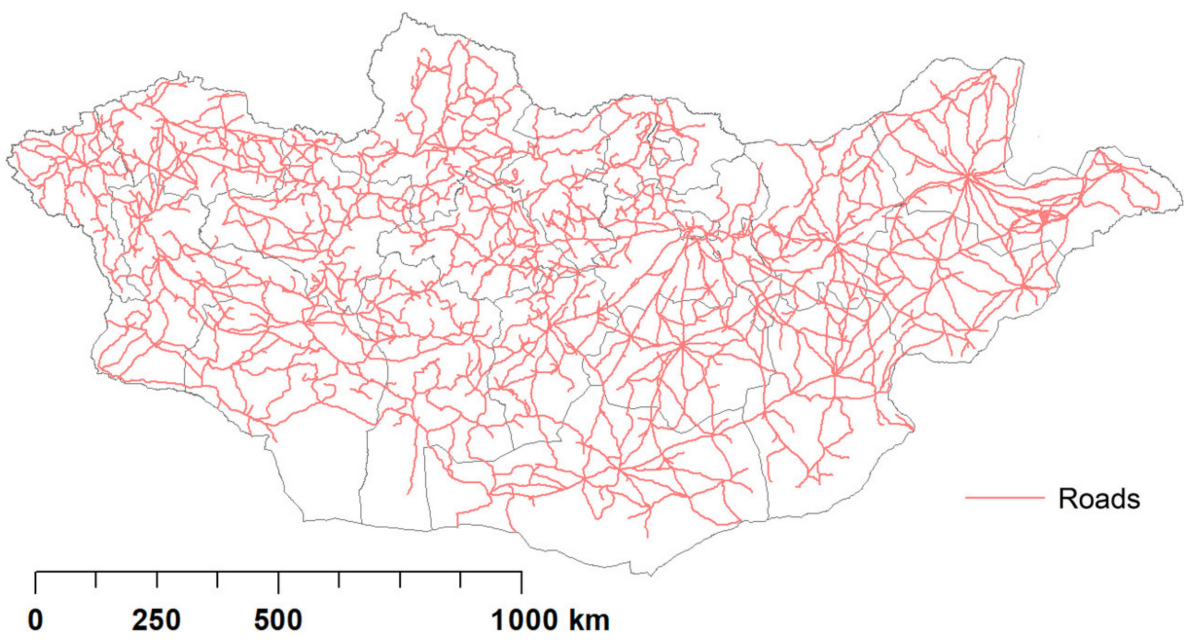

Figure 8. Main roads in Mongolia. 


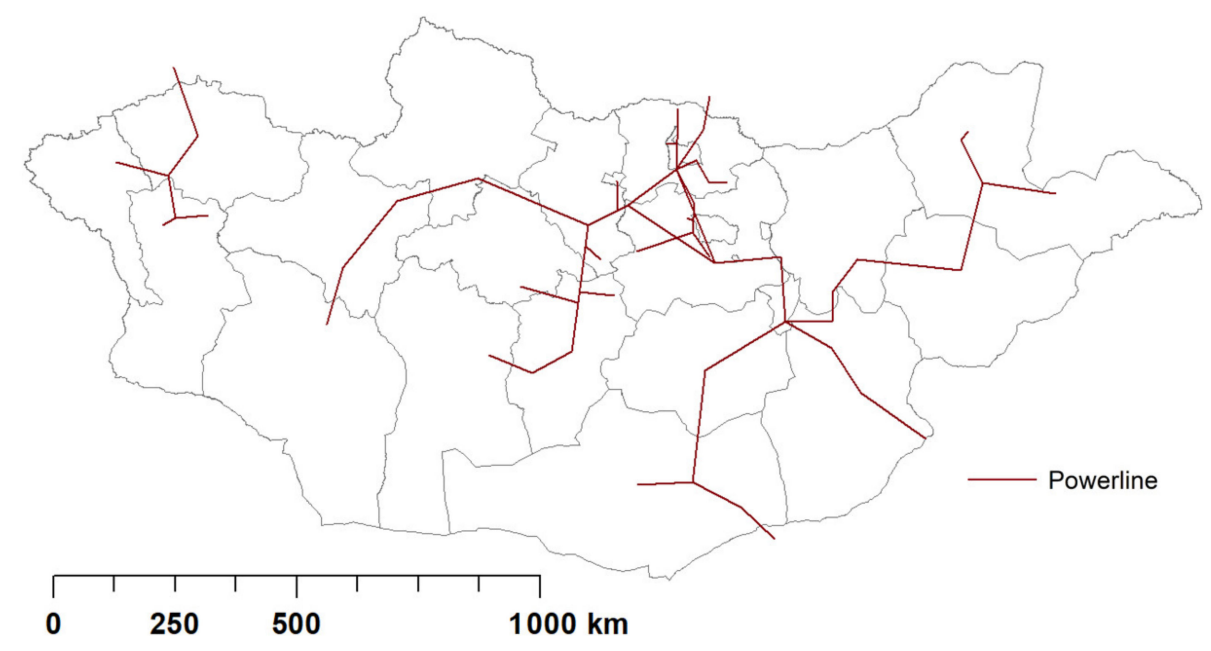

Figure 9. Major power transmission lines in Mongolia.

\subsection{Rating Criteria}

Because the PV site suitability of Mongolia was analyzed through comparison, this study assigned rated values of $100,75,50$, and 25 for seven criteria on a relative scale, where the conditions at the applicable site were evaluated as good, fair, low, or poor, respectively (Table 3). The class ranges were mostly set at equal intervals between the good and poor ratings.

PV systems require at least $4 \mathrm{kWh} / \mathrm{m}^{2} /$ day of solar irradiance for economic use, owing to the efficiency of PV systems in the sunlight zone [16]. Many previous studies on site suitability analysis for PV systems considered that slopes $>3 \%$ are typically unsuitable for PV system installation, as panels will shade adjacent rows, reducing the PV system's efficiency, and thereby impacting economic viability $[9,15,18]$. Therefore, in this study, areas with slopes $<3 \%$ and located in the south, southeast, or southwest were highly rated. In addition, areas with distances of $<25 \mathrm{~km}$ from main roads and power transmission lines were rated as good sites for installing PV power plants.

\subsection{Weighting Criteria}

The AHP method was developed by Saaty, and has been used for decision-making, especially for determining weightings for multiple criteria [10]; it has the advantage of minimizing comparisons of complex decisions in pairs. This method is also an important technique that can check the consistency of decisions, and reduce any bias that may apply to decision analyses. Then, a pairwise comparison matrix $(\mathrm{M})$ is created, as shown in Equation (1). If $n$ is the number of criteria, the size of $M$ is $n \times n$.

$$
\mathbf{M}=\left[\begin{array}{ccc}
1 & p & q \\
1 / p & 1 & r \\
1 / q & 1 / r & 1
\end{array}\right]
$$

Here, each element of $\mathrm{M}$ indicates the relative importance of the two criteria, using a numerical scale from 1 to 9 , as evaluated by experts [28].

To calculate the weight of each criterion, the elements of the column must be divided by the sum of the elements of the same column, thereby normalizing M. The average of the rows of the new matrix provides the required relative test weights. The consistency of a weight determined by the AHP method can be checked by calculating the consistency ratio $(\mathrm{CR})$. To calculate the $\mathrm{CR}$, the consistency index $(\mathrm{CI})$ must first be calculated using Equation (2):

$$
\mathrm{CI}=\frac{\lambda_{\mathrm{Max}}-n}{n-1} .
$$


where $\lambda_{\operatorname{Max}}$ is the largest eigenvalue of the comparison matrix, and $n$ is the number of criteria. Finally, the $\mathrm{CR}$ was calculated by dividing the $\mathrm{CI}$ by the randomness index (RI), as shown in Equation (3). Here, the RI values for the corresponding $n$ values were considered. Notably, to achieve significant results using the AHP, the CR must be $\leq 10 \%$; otherwise, the pair comparison values would need to be recalculated [29].

$$
\mathrm{CR}=\mathrm{CI} / \mathrm{RI}
$$

Table 3. Rating criteria used in this study.

\begin{tabular}{|c|c|c|c|}
\hline Criterion & Class & Rated Value & Remark \\
\hline \multirow{4}{*}{$\begin{array}{c}\text { Global Horizontal } \\
\text { Irradiation } \\
\left(\mathrm{kWh} / \mathrm{m}^{2} / \text { day }\right)\end{array}$} & $4.62-4.94$ & 100 & Good \\
\hline & $4.31-4.62$ & 75 & Fair \\
\hline & $4.00-4.31$ & 50 & Low \\
\hline & $<4.00$ & 25 & Poor \\
\hline \multirow{4}{*}{ Temperature $\left({ }^{\circ} \mathrm{C}\right)$} & $-20-0$ & 100 & Good \\
\hline & $0-3$ & 75 & Fair \\
\hline & $3-6$ & 50 & Low \\
\hline & $6-10$ & 25 & Poor \\
\hline \multirow{4}{*}{ Elevation (m asl) } & $3318-4318$ & 100 & Good \\
\hline & $2023-3023$ & 75 & Fair \\
\hline & 1023-2023 & 50 & Low \\
\hline & $523-1023$ & 25 & Poor \\
\hline \multirow{4}{*}{ Slope $(\%)$} & $<1$ & 100 & Good \\
\hline & $1-3$ & 75 & Fair \\
\hline & $3-11$ & 50 & Low \\
\hline & $>11$ & 25 & Poor \\
\hline \multirow{4}{*}{ Aspect } & $S$ & 100 & Good \\
\hline & SE or SW & 75 & Fair \\
\hline & E or W & 50 & Low \\
\hline & Others & 25 & Poor \\
\hline \multirow{4}{*}{$\begin{array}{l}\text { Distance from a main } \\
\operatorname{road}(\mathrm{km})\end{array}$} & $<25$ & 100 & Good \\
\hline & $25-50$ & 75 & Fair \\
\hline & $50-75$ & 50 & Low \\
\hline & $>75$ & 25 & Poor \\
\hline \multirow{4}{*}{$\begin{array}{l}\text { Distance from a major } \\
\text { power line }(\mathrm{km})\end{array}$} & $<25$ & 100 & Good \\
\hline & $25-50$ & 75 & Fair \\
\hline & $50-75$ & 50 & Low \\
\hline & $>75$ & 25 & Poor \\
\hline
\end{tabular}

\subsection{Generating a Suitability Map}

In this study, the rated value for each criterion was multiplied by its weight from the pairwise comparison, and the results were accumulated, as shown in Equation (4):

$$
\mathrm{S}=\sum_{i} w_{i} \mu_{i}
$$


where $\mathrm{S}$ represents the final score, $w_{i}$ represents the weight of criterion $i$, and $\mu_{i}$ represents the criterion's standardized score. As the criterion weights were all summed to one, the final scores of the combined solution can be expressed using the same scale. In addition, the weightings given to each criterion determined the trade-off level relative to other criteria, which implied that high scores and weightings from standardized criteria could compensate for low scores from other criteria.

\section{Results}

Rating maps of the site suitability criteria for PV arrays in Mongolia are shown in Figure 10. Values of 25, 50,75, or 100 for each of the seven GIS layers were assigned to each cell (spatial resolution: $30 \mathrm{~m}^{2}$ ), using the criteria shown in Table 3. Ten experts participated in the AHP survey-five from Mongolia and five from Korea-all of whom were professors or electricians employed in the energy and electricity sectors. All of the participants have more than 10 years of experience and expertise in PV power plants.

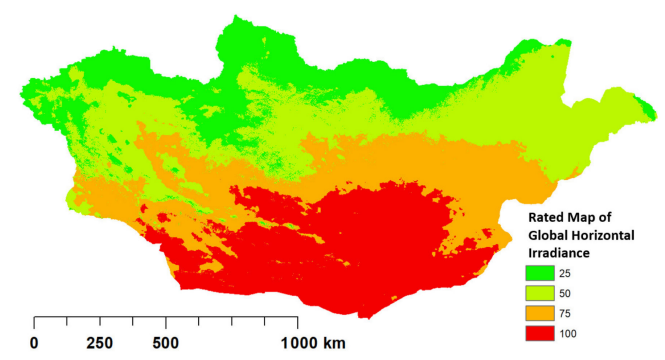

(a)

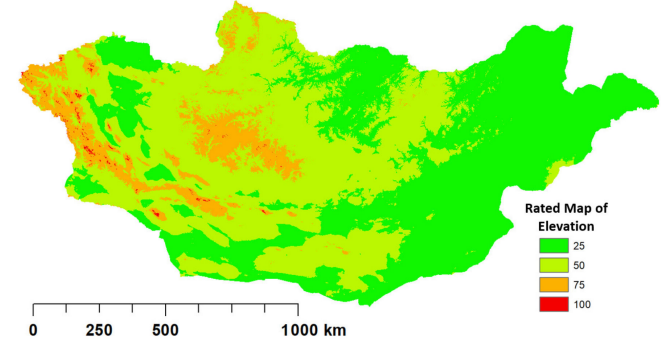

(c)

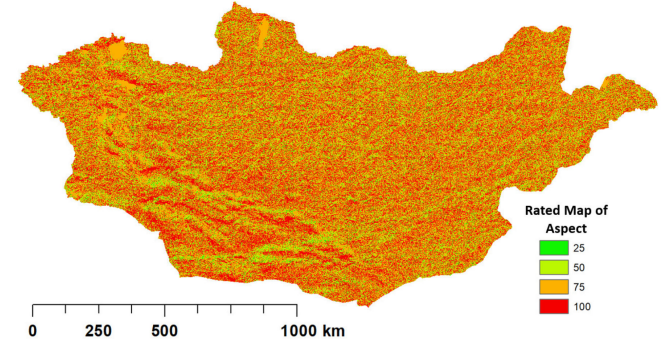

(e)

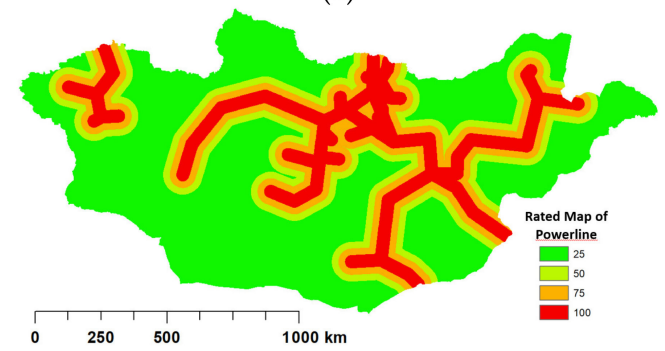

(g)

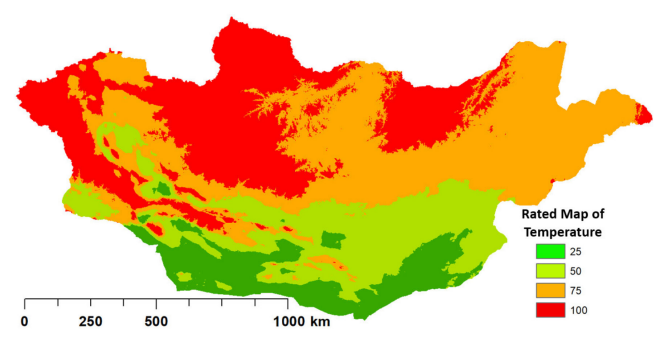

(b)

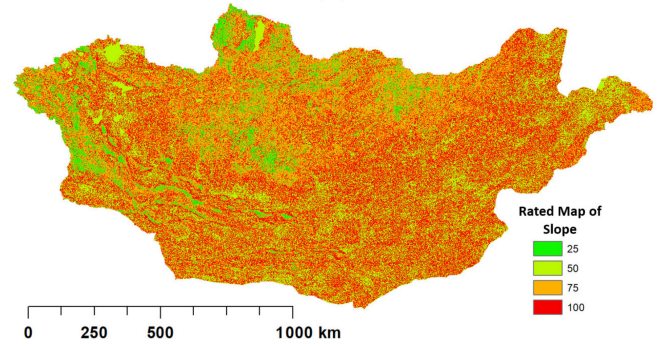

(d)

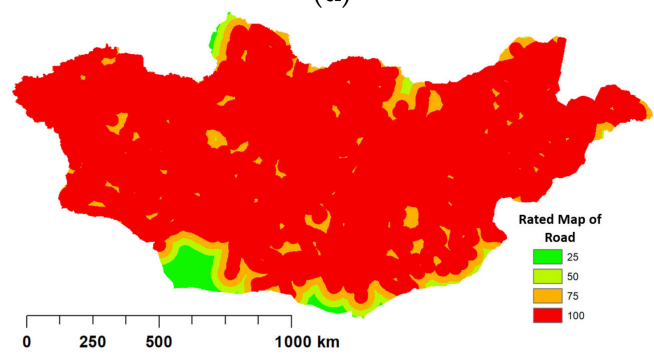

(f)

Figure 10. Criteria rating maps used in this study for Mongolian PV site suitability analysis: (a) global horizontal irradiation; (b) temperature; (c) elevation; (d) slope; (e) aspect; (f) distance from a main road; and (g) distance from a major powerline. 
The AHP results are provided in Table 4, indicating that global solar irradiance has the highest weight $(43 \%)$, followed by slope $(12 \%)$, distance from a major power line $(12 \%)$, aspect $(11 \%)$, and distance from a main road $(9 \%)$. As the CR was $6 \%$, the results of the pairwise comparisons for this study were acceptable, and the values were regarded as stable.

Table 4. Pairwise comparison matrix, the weights allocated to each criterion, and the consistency ratio (CR).

\begin{tabular}{cccccccccccc}
\hline & $\mathbf{1}$ & $\mathbf{2}$ & $\mathbf{3}$ & $\mathbf{4}$ & $\mathbf{5}$ & $\mathbf{6}$ & $\mathbf{7}$ & Weight & CR \\
\hline GHI & 0.448 & 0.444 & 0.307 & 0.473 & 0.516 & 0.390 & 0.448 & 0.43 \\
\hline Temperature & 0.064 & 0.063 & 0.152 & 0.059 & 0.046 & 0.063 & 0.058 & 0.07 \\
\hline Elevation & 0.071 & 0.020 & 0.049 & 0.018 & 0.068 & 0.088 & 0.061 & 0.06 \\
\hline Slope & 0.091 & 0.102 & 0.267 & 0.096 & 0.097 & 0.104 & 0.074 & 0.12 \\
\hline Aspect & 0.089 & 0.139 & 0.073 & 0.101 & 0.102 & 0.148 & 0.124 & 0.11 \\
\hline $\begin{array}{c}\text { Distance from } \\
\text { main road }\end{array}$ & 0.113. & 0.098 & 0.054 & 0.091 & 0.068 & 0.098 & 0.112 & 0.09 \\
\hline $\begin{array}{c}\text { Distance from } \\
\text { major power line }\end{array}$ & 0.124 & 0.135 & 0.098 & 0.162 & 0.102 & 0.109 & 0.124 & 0.12 \\
\hline
\end{tabular}

The suitability map, with areas rated as having good, fair, low, and poor conditions for installing PV power plants in Mongolia, is shown in Figure 11. The areas rated as having good conditions accounted for $3.27 \%$ of the total area, with the majority rated as having either fair $(53.06 \%)$ or low $(42.59 \%)$ conditions.

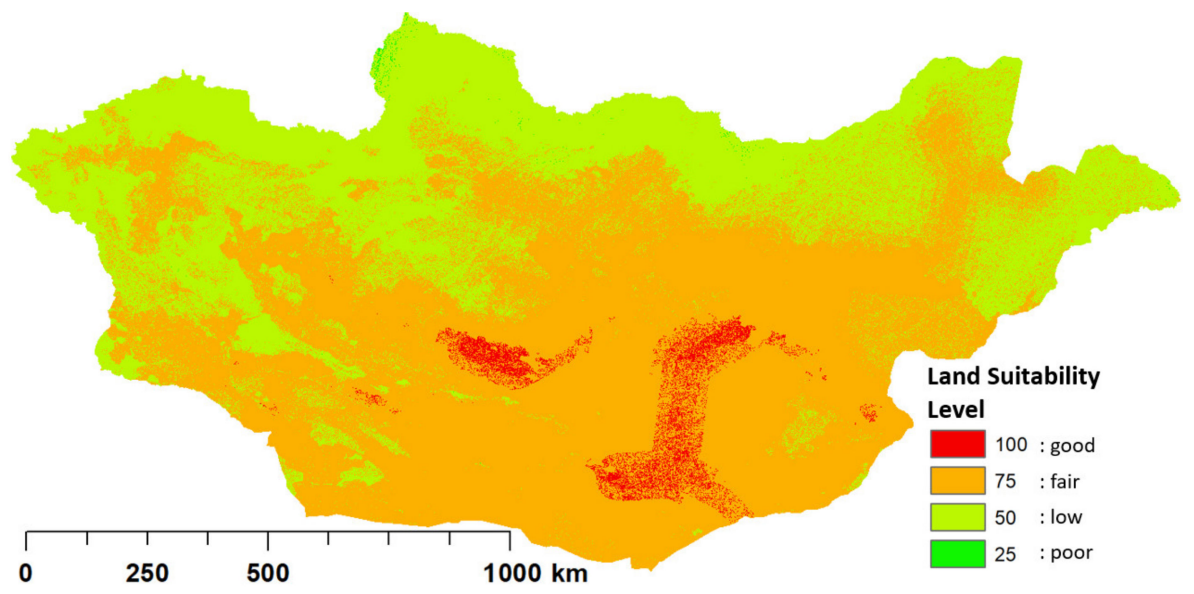

Figure 11. Suitability map for installing PV systems in Mongolia.

Areas rated as good should be considered first when planning the construction of a PV power plant in Mongolia.

\section{Discussion}

The suitability map generated for installing PV systems was statistically analyzed by considering the administrative areas (Figure 1), as presented in Table 5. Among the five administrative areas, the southern area showed the highest mean score for suitability, at 78.72 (between fair and good conditions), followed by the center (65.68), Altai-Uliastai (65.01), eastern (57.83), and western areas (55.31). The suitability score's standard deviation in the southern area was also lower than that in the other areas (8.99). 
Table 5. Statistical analysis of each Mongolian administrative area's suitability score.

\begin{tabular}{cccccccc}
\hline & Min & Max & Range & Mean & $\begin{array}{c}\text { Standard } \\
\text { Deviation }\end{array}$ & Majority & Minority \\
\hline Center & 25 & 100 & 75 & 65.68 & 14.42 & 75 & 25 \\
\hline Eastern & 25 & 75 & 50 & 57.83 & 11.75 & 50 & 25 \\
\hline Altai-Uliastai & 25 & 100 & 75 & 65.01 & 12.55 & 75 & 75 \\
\hline Southern & 25 & 100 & 75 & 78.72 & 8.99 & 11.18 & 50 \\
\hline Western & 25 & 75 & 50 & 55.31 & 25 & 75 \\
\hline
\end{tabular}

Approximately $80 \%$ of Mongolia's population is concentrated in the central area [30,31], which consumes most of Mongolia's electricity, as shown in Figure 12. The central area's power systems import approximately 300 million kWh of electricity annually from Russia, mostly during peak periods [22]. The present results show that the mean suitability value for PV systems in the central area is 65.68, demonstrating a level of installation suitability conditions rated between low and fair, with a standard deviation of 14.42. Considering its population and power consumption, the central area should therefore be prioritized for the installation of PV power plants.

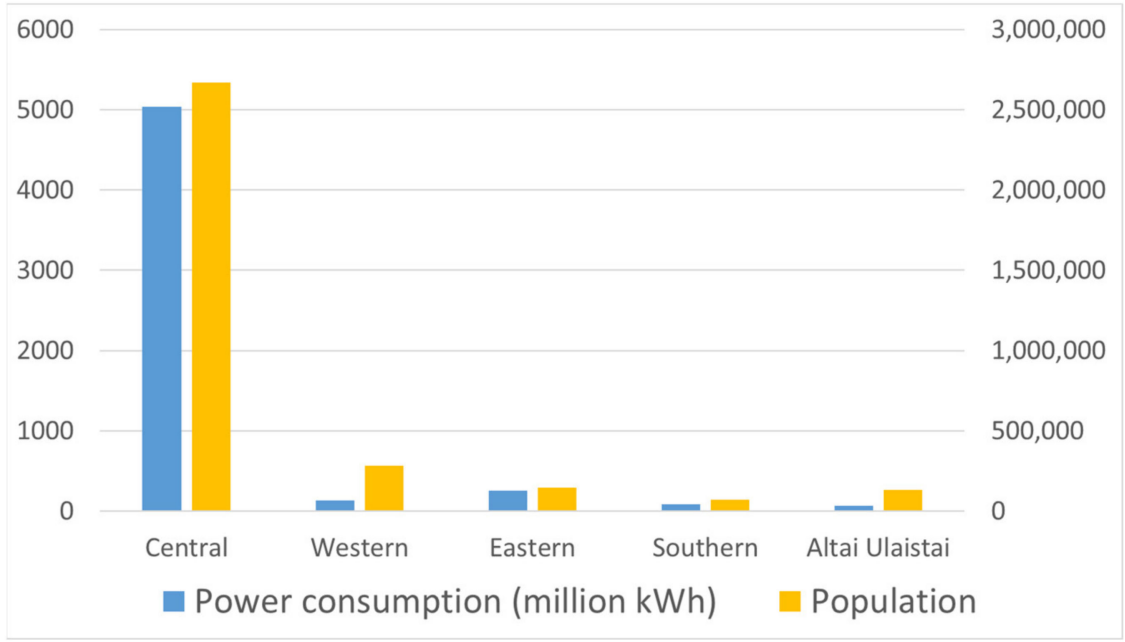

Figure 12. Power consumption and population for each Mongolian regional administrative area.

The southern area, which has the highest mean suitability score, includes the Gobi steppe, and is home to Mongolia's largest gold and copper mine, the Oyu Tolgoi mine. Approximately 1.1 billion $\mathrm{kWh}$ is annually imported from China for operations at this mine, suggesting that installing PV systems in the southern area could supply supplementary power to this mine.

\section{Conclusions}

In this study, we identified areas that are potentially suitable for the installation of large-scale PV power plants. Seven criteria, including annual global horizontal radiation, temperature, elevation, slope, aspect, distance from a main road, and distance from a major power line, were considered, and were formulated using GIS into a database as raster datasets, at a $30 \times 30 \mathrm{~m}$ resolution. The GIS layers were rated at four grades $(25,50,75$, and 100 ), and their weightings were determined using the AHP, by considering the opinions of 10 experts from the solar-electric field. By combining the seven rated GIS layers with their weightings, a PV system installation suitability map, which classified areas of Mongolia into good, fair, low, and poor site suitability grades, was created. Areas with good and fair grades accounted for $3.27 \%$ and $53.06 \%$ of Mongolia, respectively, whereas low and 
poor grades accounted for $42.59 \%$ and $1.08 \%$, respectively. Areas with good grades were concentrated in southern and central Mongolia; hence, considering power demand and population, the central area was selected as the top priority for installing PV power plants.

In recent years, the global trend in the use of renewable energy has been increasing, with emerging interest in it as an investment. The national government has begun implementing targeted policies to support renewable energy in Mongolia, which currently supplies only $17 \%$ of its domestic energy capacity. The main issues related to large solar installations are high investment costs and identifying the most suitable plant locations, and resolving these issues can be considered the most important step in the development of this sector. Therefore, by offering screening data for PV site suitability analysis for Mongolia, the findings of this study are expected to benefit researchers, industry professionals, and policy-makers. Referring to these data can positively bridge the communications and decision-making gaps between academia, industry, and the general public.

There are a few limitations to this study. First, this study used the GHI data obtained from the Global Solar Atlas [16]; however, no comparison between the GHI data used in this study and those measured at the ground stations was performed, because climate data are limited in Mongolia. GHI data collected at many ground stations in Mongolia can provide more accurate results of PV site suitability through the verification of data. Second, this study analyzed the PV site suitability at the national scale, considering seven criteria. For the actual implementation of PV power plants, detailed analysis is required, considering additional criteria and high-resolution spatial data that can be obtained at the local scale. Third, this study analyzed PV site suitability by comparison and, therefore, the rated values were given for the seven criteria on a relative scale of good, fair, low, or poor. More justifications on the rating criteria are needed in order to conclusively evaluate PV site suitability. Therefore, future research activities must include improving the combination between GIS and MCDA methods in order to comprehensively analyze PV site suitability in Mongolia using more reliable and verified data obtained at the local scale.

Author Contributions: Conceptualization, Y.C.; methodology, Y.C. and U.M.; software, Y.C.; validation, U.M.; formal analysis, U.M.; investigation, U.M.; resources, Y.C.; data curation, U.M.; writing-original draft preparation, Y.C. and U.M.; writing—review and editing, Y.C.; visualization, Y.C. and U.M.; supervision, Y.C.; project administration, Y.C.; funding acquisition, Y.C. All authors have read and agreed to the published version of the manuscript.

Funding: This work was supported by the KETEP grant funded by the Korean government's Ministry of Trade, Industry and Energy (project no. 20206110100030).

Institutional Review Board Statement: Not applicable.

Informed Consent Statement: Not applicable.

Conflicts of Interest: The authors declare no conflict of interest.

\section{References}

1. U.S. Energy Information Administration. Available online: https://www.eia.gov/todayinenergy/detail.php?id=41433/ (accessed on 25 February 2021).

2. Tahri, M.; Hakdaoui, M.; Maanan, M. The evaluation of solar farm locations applying Geographic Information System and Multi-Criteria Decision-Making methods: Case study in southern Morocco. Renew. Sustain. Energy Rev. 2015, 51, 1354-1362. [CrossRef]

3. Global Energy Institute. Available online: https://www.globalenergyinstitute.org/look-ieas-new-global-energy-forecast/ (accessed on 25 February 2021).

4. Lukac, N.; Zlaus, D.; Seme, S.; Žalik, B.; Štumberger, G. Rating of roofs surfaces regarding their solar potential and suitability for PV systems, based on LiDAR data. Appl. Energy 2013, 102, 803-812. [CrossRef]

5. Al Garni, H.Z.; Awasthi, A. Solar PV power plant site selection using a GIS-AHP based approach with application in Saudi Arabia. Appl. Energy 2017, 206, 1225-1240. [CrossRef]

6. Choi, Y.; Rayl, J.; Tammineedi, C.; Brownson, J.R.S. PV Analyst: Coupling ArcGIS with TRNSYS to assess distributed photovoltaic potential in urban areas. Sol. Energy 2011, 85, 2924-2939. [CrossRef] 
7. Choi, Y.; Suh, J.; Kim, S.-M. GIS-Based Solar Radiation Mapping, Site Evaluation, and Potential Assessment: A Review. Appl. Sci. 2019, 9, 1960. [CrossRef]

8. Malczewski, J. GIS-based multicriteria decision analysis: A survey of the literature. Appl. Sci. 2006, 20, 703-726. [CrossRef]

9. Uyan, M. GIS-based solar farms site selection using analytic hierarchy process (AHP) in Karapinar region, Konya/Turkey. Renew. Sustain. Energy Rev. 2013, 28, 11-17. [CrossRef]

10. Ziuku, S.; Seyitini, L.; Mapurisa, B.; Chikodzi, D.; Kuijk, K. Potential of Concentrated Solar Power (CSP) in Zimbabwe. Energy Sustain. Dev. 2014, 23, 220-227. [CrossRef]

11. Watson, J.J.W.; Hudson, M.D. Regional Scale wind farm and solar farm suitability assessment using GIS-assisted multi-criteria evaluation. Landsc. Urban Plan. 2015, 138, 20-31. [CrossRef]

12. Aly, A.; Jensen, S.S.; Pedersen, A.B. Solar power potential of Tanzania: Identifying CSP and PV hot spots through a GIS multicriteria decision making analysis. Renew. Energy 2017, 113, 159-175. [CrossRef]

13. Yushchenko, A.; de Bono, A.; Chatenoux, B.; Patel, M.K.; Ray, N. GIS-based assessment of photovoltaic (PV) and concentrated solar power (CSP) generation potential in West Africa. Renew. Sustain. Energy Rev. 2018, 81, 2088-2103. [CrossRef]

14. Merrouni, A.A.; Elalaoui, F.E.; Mezrhab, A.; Mezrhab, A.; Ghennioui, A. Large scale PV sites selection by combining GIS and Analytical Hierarchy Process. Case study: Eastern Morocco. Renew. Energy 2018, 119, 863-873. [CrossRef]

15. Asakereh, A.; Omid, M.; Alimardani, R.; Sarmadian, F. Developing a GIS-based Fuzzy AHP Model for Selecting Solar Energy Sites in Shodirwan Region in Iran. Int. J. Adv. Sci. Technol. 2014, 68, 37-48. [CrossRef]

16. Noorollahi, E.; Fadai, D.; Shirazi, M.A.; Ghodsipour, S.H. Land Suitability Analysis for Solar Farms Exploitation Using GIS and Fuzzy Analytic Hierarchy Process (FAHP)-A Case Study of Iran. Energies 2016, 9, 643. [CrossRef]

17. Suh, J.; Brownson, J.R.S. Solar farm suitability using geographic information system fuzzy sets and analytic hierarchy processes: Case study of Ulleung Island, Korea. Energies 2016, 9, 648. [CrossRef]

18. Sánchez-Lozano, J.M.; Teruel-Solano, J.; Soto-Elvira, P.L.; García-Cascales, M.S. Geographical Information Systems (GIS) and Multi-Criteria Decision Making (MCDM) methods for the evaluation of solar farms locations: Case study in south-eastern Spain. Renew. Sustain. Energy Rev. 2013, 24, 544-556. [CrossRef]

19. Wikipedia. Available online: https://en.wikipedia.org/wiki/Mongolia (accessed on 25 February 2021).

20. Energypedia. Available online: https://energypedia.info/wiki/Mongolia_Energy_Situation/ (accessed on 25 February 2021).

21. Mongolian Ministry of Energy. Available online: http:/ / energy.gov.mn/c/1129 (accessed on 25 February 2021).

22. Energy Regulatory Commission. Available online: https://erc.gov.mn/web/mn/print/337?date=true (accessed on 25 February 2021).

23. Legalinfo. Available online: https:/ / www.legalinfo.mn/annex/details/3220?lawid=6485/ (accessed on 25 February 2021).

24. Global Solar Atlas. Available online: https://globalsolaratlas.info/download/mongolia/ (accessed on 25 February 2021).

25. National Agency Meteorology and the Environmental Monitoring. Available online: http://tsag-agaar.gov.mn/atmosphere/ (accessed on 25 February 2021).

26. Batchuluun, E.; Ymchaa, G.; Ser-Od, T.; Tsendsuren, T.; Odmandah, L. Geography VIII, 2nd ed.; Munkhiin Useg LLC: Ulaanbaatar, Mongolia, 2019; p. 34. ISBN 978-99978-61-09-2.

27. Charabi, Y.; Gastli, A. PV site suitability analysis using GIS-based spatial fuzzy multi-criteria evaluation. Renew. Energy 2011, 36, 2554-2561. [CrossRef]

28. Saaty, T.L. How to make a decision: The analytic hierarchy process. Eur. J. Oper. Res. 1990, 48, 9-26. [CrossRef]

29. Saaty, T.L. Decision making with the analytic hierarchy process. Int. J. Serv. Sci. 2008, 1, 83-98. [CrossRef]

30. Energy Regulatory Commission. Available online: https:/ / erc.gov.mn/web/mn/ (accessed on 25 February 2021).

31. National Statistics Office of Mongolia. Available online: http:/ / www.nso.mn/ (accessed on 25 February 2021). 